\title{
Bacterial Flora of Water and Rotifers in Outdoor Mass Culture Tanks Fed with Different Microalagal Diets
}

Jayasree Loka, Sonali S. M., Purbali Saha and Philipose K. K.

Karwar Research Centre of CMFRI, Post Box No. 5, Karwar, North Kanara 581301, Karnataka, India

\begin{abstract}
Investigations were carried out on the bacterial flora of water and the quality of rotifers in outdoor mass culture tanks. Brachionus plicatilis and B. rotundiformis were cultured in 10 numbers of 1 tonne tanks and the physico-chemical parameters and microbial loads of water, and total bacterial and Vibrio loads of microalgae and rotifers, during the period 2014-15, were studied. The study revealed a significant variation of the ammonia levels and total bacterial loads with different diets $(P<0.05)$. A positive correlation was observed between the total bacterial loads of algal concentrations and loads of rotifers, but no correlation was observed between Vibrio loads of water and rotifers. The prevalence of Vibrio loads of rotifers was low in tanks fed with Nannochloropsis oculata and maximum Vibrio loads were recorded in Chaetoceros calcitrans fed rotifers. The Vibrio loads significantly varied with days of culture and also with the algal diets. A positive correlation was observed between the total Vibrio loads of water and rotifers.
\end{abstract}

Key words: Brachionus plicatilis, B. rotundiformis, marine microalgae, bacterial flora.

\section{Introduction}

For several decades, Brachionus plicatilis is one of the most important starter feeders used in the initial stages of fish larval stages and has been used in fish hatcheries. Due to their smaller size and faster rate of reproduction, these rotifers are being cultured on a mass scale as a feed for fish larviculture. Significant research contributions were made on the nutritional aspects of these rotifers in association with density [1]. The success of rotifer mass cultures is determined not only by the higher density, but also by their nutritional composition and their associated microbiota [2-4]. Health and survival of fish larvae depend on the quality of feed given and hence it is essential to understand the health status of rotifers before they are fed to fish fry. Although few studies in this aspect have been carried out worldwide [3-6], studies in India were found meagre. The present paper deals with the association of microbial flora of live feed in relation to the microalgal diets and water quality in

Corresponding author: Jayasree Loka, research field: marine microbiology. outdoor mass culture tanks.

\section{Materials and Methods}

A study was carried out on the quality of rotifers in marine hatchery during 2014-15. Rotifers were grown semi-continuously on Chlorella vulgaris in 1,000 L tanks with a density of 100 rotifers ml-. Rotifers were fed with Nannochloropsis oculata, Isochrysis galbana, Chlorella vulgaris, Chaetoceros calcitrans and combination of Nannochloropsis and Isochrysis. For each diet, duplicates were maintained. For every three days, total bacterial and total Vibrio loads were estimated from water and rotifer samples following standard protocols. In brief, water samples were serially diluted and pour plated on Zobell Marine agar and TCBS agar, following standard procedures. Rotifers and microalgae were rinsed with sterile seawater and $0.1 \mathrm{~g}$ of sample was suspended and homogenised in $1 \mathrm{~mL}$ of sterile seawater. Serial dilutions were made and pour plated on Zobell Marine agar and TCBS agars and the loads were estimated after $24 \mathrm{~h}$ incubation. Water quality parameters (Temperature, Salinity, pH, Dissolved oxygen and 
Ammonia) were also recorded at the time of sampling. The data was analysed using one-way and two-way ANOVA for significant occurrence of Vibrio between the treatments.

\section{Results and Discussion}

\subsection{Microbial Loads of Water in Rotifer Tanks}

Total bacterial loads were observed to be very high in the water and also rotifers fed with $C$. calcitrans (Fig. 1). Maximum total bacterial loads and total Vibrio loads in tank water fed with $C$. calcitrans were $0.22 \times 10^{7} \mathrm{cfu} / \mathrm{ml}$ and $0.15 \times 10^{6} \mathrm{cfu} / \mathrm{ml}$ respectively and minimum values were observed in tank water with I. galbana. Total bacterial counts of water were low in tanks fed with I. galbana and varied between $0.79 \times 10^{2}-0.225 \times 10^{3} \mathrm{cfu} / \mathrm{ml}$. The total bacterial

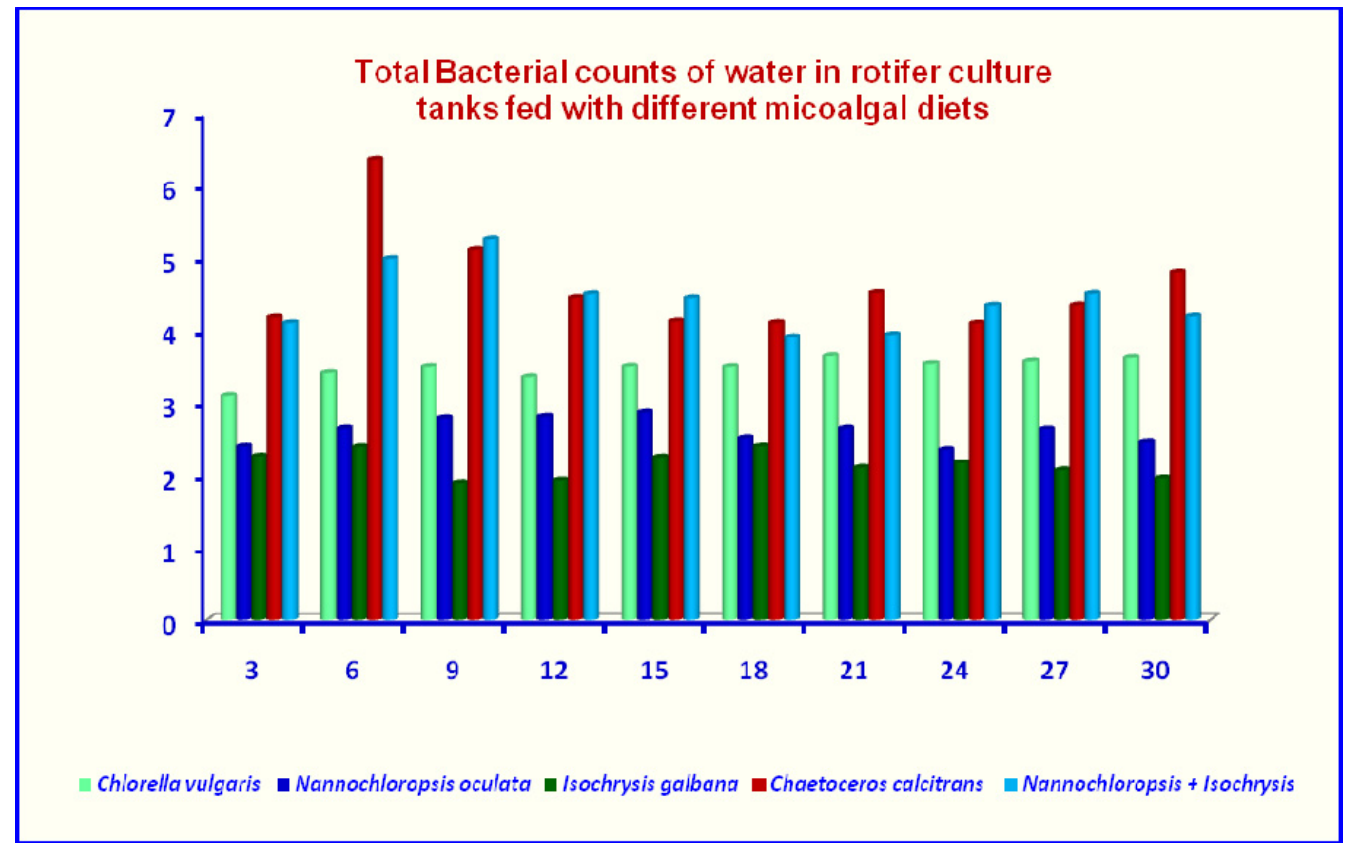

(a)

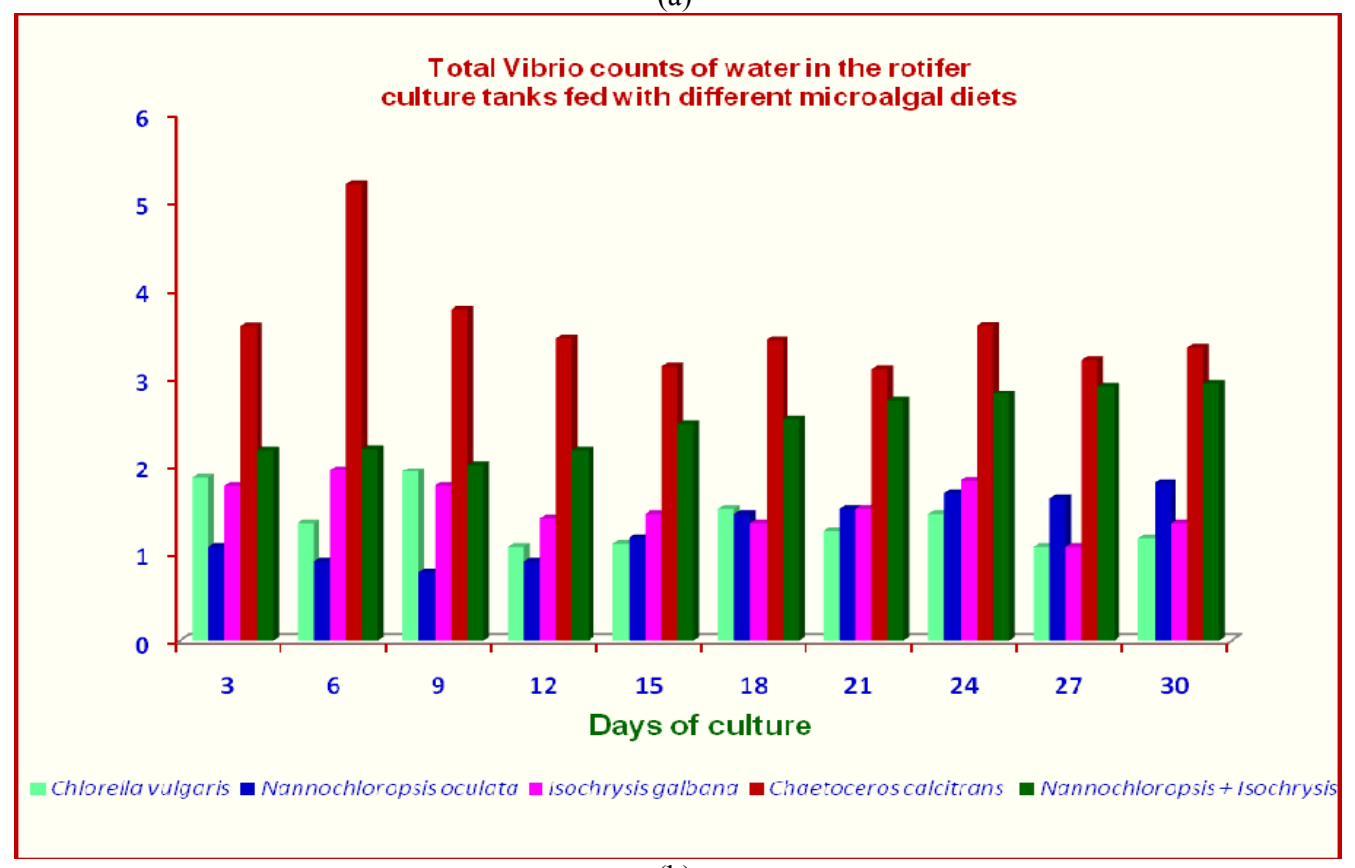

(b)

Fig. 1 Total Bacterial Loads and total Vibrio loads of water in rotifer tanks fed with different microalgal diets. 
loads were observed to be low initially in the tanks fed with algal diets other than C. calcitrans, but increased from 10th day onwards with partial water exchange. Maximum Vibrio loads of water in rotifer tanks fed with $C$. calcitrans were recorded with a density of $0.15 \times 10^{6} \mathrm{cfu} / \mathrm{ml}$, whereas, minimum of 6 colonies were recorded from tanks fed with $N$. oculata. It was observed that lower bacterial loads were recorded in tanks fed with I. galbana but the Vibrio loads of water were less in tanks fed with $N$. occulata. A positive correlation was observed between the total bacterial loads and Vibrio loads of water of all the tanks ( $\mathrm{r}=$ +052 ), where as a significant variation was observed between the Vibrio loads of water between the algal diets $(P<0.05)$.

\subsection{Microbial Loads of Rotifers and Microalgae}

Total Vibrio loads of microalgae varied between a maximum of $0.1 \times 10^{6} \mathrm{cfu} / \mathrm{g}$ in rotifer tanks with $C$. calcitrans and minimum of $1.2 \times 10^{2} \mathrm{cfu} / \mathrm{g}$ in tanks with I. galbana. Whereas, the Vibrio loads of rotifers varied from $0.5 \times 10^{1} \mathrm{cfu} / \mathrm{g}$ and $0.24 \times 10^{6} \mathrm{cfu} / \mathrm{g}$ in tanks fed with $N$. oculata and $C$. calcitrans respectively. A strong positive correlation was observed between the total bacterial loads and Vibrio loads of algal concentrations and loads of rotifers (Table 1). Analysis of Variance revealed a significant variation between the bacterial loads of rotifers and also microalgal diets (Figs. $2 \& 3$ ). The study indicated that the occurrence of Vibrio was high in the rotifer tanks fed with algal diet of $C$. calcitrans and minimum in $N$. oculata, indicating a direct impact of algal diet on the quality of rotifers. Ammonia levels in the tank waters also varied significantly $(P>0.05)$ between the diets and highest ammonia levels were recorded in C. calcitrans tanks. A direct positive correlation was also recorded between ammonia levels and Vibrio loads of water in tanks with C. calcitrans. $(r=0.58)$. Maximum Density of rotifers was found in tanks fed with $N$. oculata, followed by the tanks fed with combined diet of $N$. oculata and I. galbana. A positive correlation was observed between rotifer density and Vibrio loads of algal diets $(r=0.68)$ indicating that the water quality plays a major role in rotifer density.

\subsection{Application of Probiotics}

Preliminary experiment was carried out, in the hatchery, on the effect of commercially available probiotics on the occurrence Vibrio loads. The experiment was conducted with algal diet, $C$. calcitrans as more Vibrio loads were recorded in those tanks, Four 1 tonne tanks were inoculated with rotifers with a density of 200 numbers $/ \mathrm{ml}$ and were fed with $C$. calcitrans and N.oculata in two tanks each. Commercial water probiotic, with a concentration of $10 \mathrm{ml}$ in 1 tonne water, was applied daily. The study revealed a significant improvement in the quality of rotifer, in terms of Vibrio loads of the rotifer. Vibrio loads of probiotic fed tank was $0.18 \times 10^{2} \mathrm{cfu} / \mathrm{g}$ and in control load was $1.8 \times 10^{1} \mathrm{cfu} / \mathrm{g}$ in $C$. calcitrans tanks. No Vibrios were detected in the tank fed with $N$. oculata along with probiotics. The role of Vibrios in live feed culture plays a significant role in terms of quality as well as quantity of rotifers.

The study also revealed that the total vibrio loads of water and rotifers were very high in C. calcitrans fed tanks, followed by tanks fed with combined diet $N$. occulata and I.galbana. It was observed that the diversity of the bacterial flora of rotifers is dependent on the flora of the rearing water [7] and $V$. alginolyticus was recorded as the most dominant

Table 1 Correlation between Total Vibrio loads of water, microalgae and rotifers.

\begin{tabular}{lllll}
\hline & C. calcitrans & N. oculata & I. galbana & C. vularis \\
\hline Rotifers & 0.532905 & 0.925928044 & 0.640333 & 0.58132 \\
Water & 0.617241 & 0.520991353 & 0.81993 & 0.571306 \\
\hline
\end{tabular}




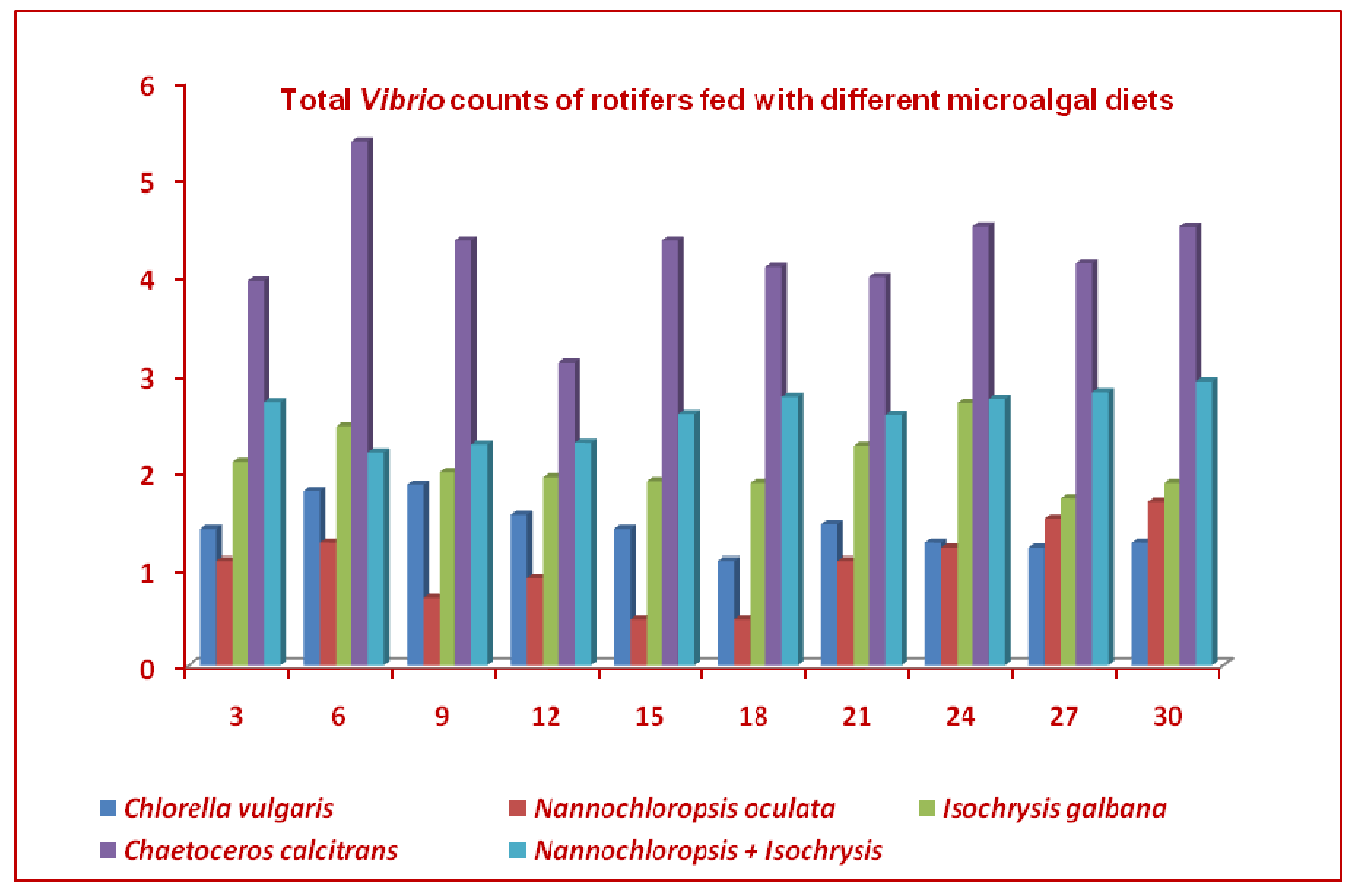

Fig. 2 Total Vibrio loads of rotifers fed with different microalgal diets.

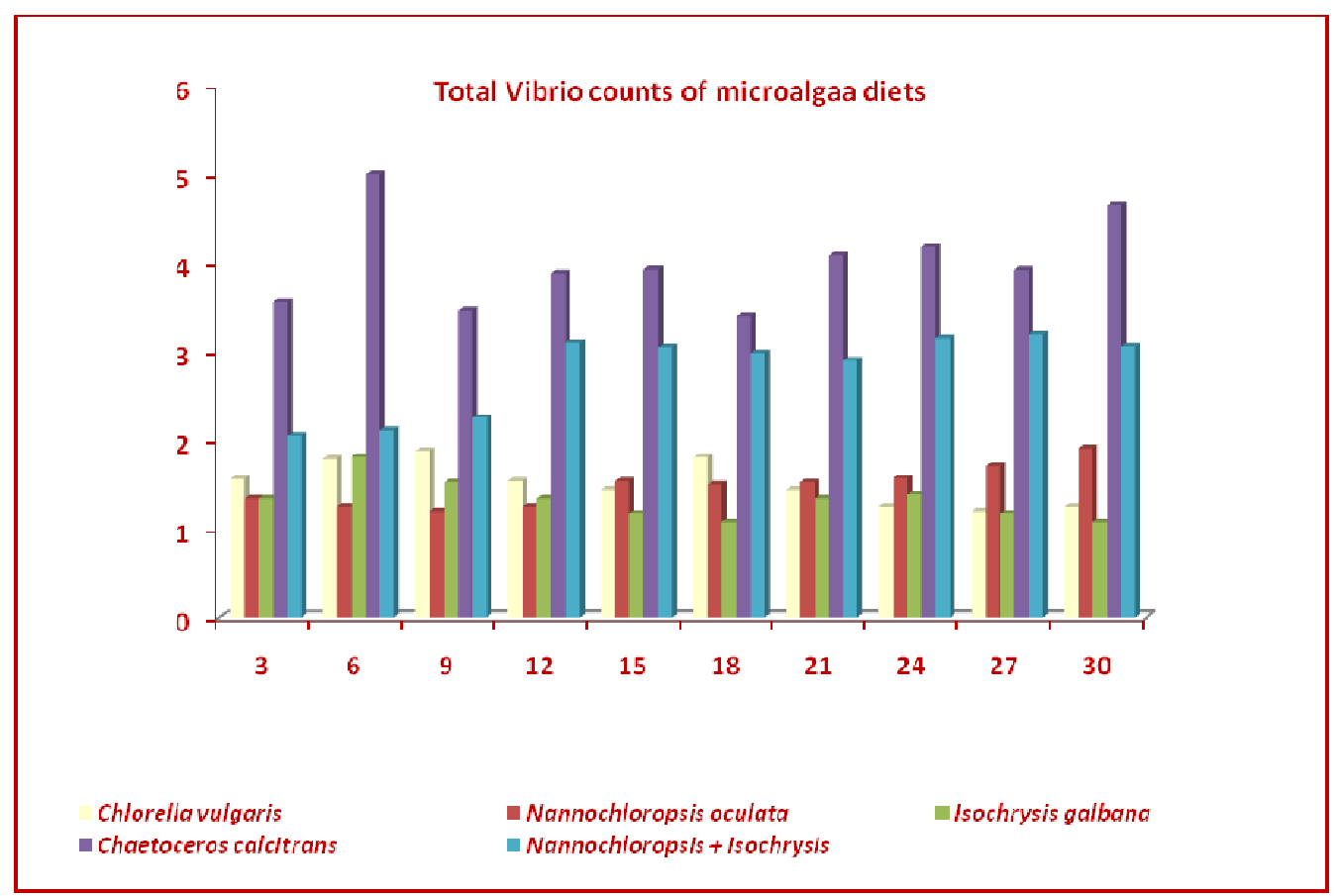

Fig. 3 Total Vibrio loads of microalgal diets fed to the rotifers in mass culture tanks.

microflora of rotifers, which produce a fatal exotoxin for B. plicatilis [8]. In contrary, $V$. anguillarum isolated and identified as the major dominant species in rotifer cultures but there was no record of mortalities due to this species [8]. High loads of total bacteria ranging between $0.9 \times 10^{8}$ and $56.6 \times 10^{8}$ $\mathrm{cfu} / \mathrm{g}$ were recorded [4] from rotifers in marine hatchery. It is hypothesized that the bacteria can be transferred either directly through seawater [10] or by ingestion [10-12]. Although majority of earlier studies indicated that bacteria are not pathogenic, the occurrence of fish larvae could be related to the 
accumulation of large quantities of these non pathogenic microbes. Many reports suggested that reduction in microbial loads can increase the larval survival in marine finfish hatcheries [13]. In the present investigation, it was clearly observed a reduction in the density of rotifers in those tanks with Vibrio loads, which may be a possible cause of algal crash and increase of ammonia levels in water, which in turn triggers the reduction of rotifer densities. Preliminary study on the effect of probiotics on the elimination of Vibrio loads, in the present investigation, also indicated a need to develop an alternate useful live organism for the elimination of contamination in mass culture systems.

\section{Acknowledgments}

Authors are thankful to the Director, Central Marine Fisheries Research Institute, Cochin, India for providing facilities to carry out this work.

\section{References}

[1] Lubzens, E., and Zmora, O. 2003. "Production and Nutritional Value of Rotifers." In: Live Feeds in Marine Aquaculture (ed. by J. G. Støttrup and L. A. McEvoy), pp. 17-64. Blackwell Science, Oxford, UK.

[2] Dhert, P., Rombaut, G., Suantika, G., and Sorgeloos, P. 2001. "Advancement of Rotifer Culture and Manipulation Techniques in Europe." Aquaculture 200: 129-46.

[3] Qi, Z. Z., Dierckens, K., Defoirdt, T., Sorgeloos, P., Boon, N., Bao, Z. M., and Bossier, P. 2009. "Analysis of the Evolution of Microbial Communities Associated with Different Cultures of Rotifer Strains belonging to Different Cryptic Species of the Brachionus plicatilis Species Complex.” Aquaculture 292: 23-9.

[4] Haché, R., and Plante, S. 2011. "The Relationship between Enrichment, Fatty Scid Profiles and Bacterial
Load in Cultured Rotifers (Brachionus plicatilis L-strain) and Artemia (Artemia salina strain Franciscana)." Aquaculture 311 (1-4): 201-8.

[5] Verdonck, L., Swings, J., Kersters, K., Dehasque, M., Sorgeloos, P., and Leger, P. 1994. "Variability of the Microbial Environment of Rotifer Brachionus plicatilis and Artemia Production Systems." J. World Aquacult. Soc. 25: 55-9.

[6] Verdonck, L., Grisez, L., Sweetman, E., Minkhoff, G., Sorgeloos, P., and Ollevier, F. J. Swings 1997. "Vibrios Associated with Routine Productions of Brachionus plicatilis." Aquaculture 149: 203-14.

[7] Tanasomwang, V., and Muroga, K. 1988. "Intestinal Microflora of Larval and Juvenile Stages in Japanese Flounder (Paralichthys olicaceus)." Fish Pathol. 23: 77-83.

[8] Yu, J. P., Hino, A., Noghchi, T., and Wakabayashi, H. 1990. "Toxicity of Vibrio alginolyticus in the Survival of the Rotifer, Brachionus plicatilis." Nippon Suisan Gakkaishi 56: 1455-60.

[9] Verdonck, L., Grisez, L., Sweetman, E., Minkoff, G., Sorgeloos, P., Ollevier, F., and Swings, J. 1997. "Vibrios Associated with Routine Productions of Brachionus Plicatilis." Aquaculture 149: 203-14.

[10] Prol-Garcia, M. J., Planas, M., and Pintado, J. 2010. "Different Colonization and Residence Time of [10] Listonella anguillarum and Vibrio splendidus in the Rotifer Brachionus plicatilis Determined by Real-time PCR and DGGE." Aquaculture 302: 26-35.

[11] Skjermo, J., and Vadstein, O. 1999. "Techniques for Microbial Control in the Intensive Rearing of Marine Larvae." Aquaculture 177: 333-43.

[12] Plante, S., Pernet, F., Hache, R., Ritchie, R., Ji, B., and McIntosh, D., 2007. "Ontogenetic Variations in Lipid Class and Fatty Acid Composition of Haddock Larvae Melanogrammus aeglefinus in Relation to Changes in Diet and Microbial Environment." Aquaculture 263: 107-21.

[13] Douillet, P. A. 2000. "Bacterial Additives that Consistently Enhance Rotifer Growth under Synxenic Culture Conditions: 1. Evaluation of Commercial Products and Pure isolates." Aquaculture 182: 249-60. 